\title{
ANALISIS REVALUASI ASET TETAP DALAM PENETAPAN PAJAK PENGHASILAN PADA PT. BANK SULUTGO
}

\author{
Stefian Polopadang ${ }^{1}$, Jantje J. Tinangon ${ }^{2}$, Inggriani Elim ${ }^{3}$ \\ 1,2,3 Jurusan Akuntansi, Fakultas Ekonomi dan Bisnis, Universitas Sam Ratulangi, Jl. Kampus Bahu, Manado, \\ 95115, Indonesia \\ E-mail : davidstevian@yahoo.com
}

\begin{abstract}
Tax is the one of the outcome of a company without making any profit directly, therefore in paying tax a company do the effort so the payment becomes a bit less without breaking the rules in tax which is prevail. One of the way to minimize the tax is using one of the accounting policies, revaluation of fixed assets. The formulation of the problem of this research is the role of revaluation of fixed assets in determining incoming tax. The kind of this research which is used, is qualitative descriptive with the theory and using the object of the research in PT. BANK SULUTGO. According to the analysis and research which is suit with regulation 36 Taxation on Income Tax Year 2008 and Decree of the Minister of Finance 486/KMK/2002 that by applying the revaluation the fair market value of the acquired fixed assets newly, where the fair market value of fixed assets can be seen the value of revaluation of fixed assets, then the amount of final income tax imposed at 6\% based on the book 2016 accrording to Minister of Finance Regilation 191 Year 2015.
\end{abstract}

Keywords: Revaluation, Fixed Asset, Income Tax

\section{PENDAHULUAN}

Semakin pesatnya pelaksanaan pembangunan di berbagai sektor industri yang didukung oleh kemajuan tekhnologi dan globalisasi pasar internasional akan berdampak pada timbulnya persaingan yang ketat di antara perusahaan, khususnya yang bergerak dalam bidang industri sejenis. Untuk mendukung kegiatan operasionalnya, setiap bentuk badan usaha yang ada saat ini mulai dari yang berukuran kecil hingga yang besar pasti akan memanfaatkan aset miliknya. Aset-aset tersebut bervariasi jenisnya tergantung pada sifat aktivitas usaha yang dijalankan perusahaan.

Dalam suatu perusahaan aset tetap merupakan suatu bagian yang sangat penting, ditinjau dari fungsinya, dana yang diinvestasikan dan pengawasannya. Aset tetap merupakan aset berwujud yang dimiliki suatu perusahaan dan digunakan dalam suatu kegiatan produksi atau penyediaan barang atau jasa, untuk direntalkan kepada pihak yang lain atau dengan tujuan administratif dan diharapkan untuk dapat digunakan selama lebih dari satu periode. Faktor yang mempengaruhi menurunnya produktivitas suatu aset tetap yaitu: secara fisik, disebabkan oleh pemakaian dan keusangan karena eksploitasi yang berlebihan dan secara fungsional, disebabkan oleh ketidakcukupan kapasitas yang tersedia dengan yang diminta, sehingga penurunan kemampuan aktiva tetap tersebut dapat dialokasikan sebagai biaya.

Pajak merupakan iuran rakyat yang sebagai Wajib Pajak kepada kas negara yang pemungutannya berdasarkan undang-undang dan bersifat memaksa dengan tidak mendapat imbalan secara langsung dan yang dapat ditunjukkan dan digunakan untuk membayar keperluan umum negara. Bagi wajib pajak, membayar pajak adalah suatu kaharusan sekalipun tidak mendapatkan imbalan secara langsung. Dan bagi perusahaan pajak merupakan salah satu pengeluaran terbesar dengan tidak mendapatkan imbalan bagi perusahaan sendiri. 
Dalam hal membayar pajak perusahaan berupaya agar pembayarannya menjadi sekecil mungkin tanpa melanggar peraturan perpajakan yang berlaku. Salah satu cara untuk meminimalkan beban pajak adalah dengan satu kebijakan akuntansi yaitu revaluasi aset tetap.

Revaluasi aset tetap adalah penilaian kembali aset tetap pada perusahaan, yang terjadi oleh karena timbulnya kenaikan harga atau nilai dari suatu aset tetap tersebut di pasaran pada saat melakukan revaluasi atau karena rendahnya pencatatan nilai aset tetap dalam laporan keuangan suatu perusahaan yang disebabkan terjadinya devaluasi atau sebab lain, sehingga nilai aset tetap yang tercatat dalam laporan keuangan suatu perusahaan tidak lagi mencerminkan nilai yang wajar. Penilaian kembali (revaluasi) aset tetap dapat meliputi seluruh atau sebagian aset tetap perusahaan, termasuk asset tetap perusahaan yang terhadapnya sudah pernah dilakukan penilaian kembali berdasarkan ketentuan yang berlaku sebelumnya. Yang menjadi objek revaluasi adalah aset tetap yang yang digunakan suatu perusahaan untuk memperoleh, menagih dan memelihara penghasilan yang adalah objek pajak.

Atas selisih revaluasi dikenakan tarif $\mathrm{PPh}$ yang bersifat final sebagaimana diatur dalam PMK-191 Tahun 2015 sesuai dengan ketentuan tahun melakukan revaluasi sebesar:

1. 3\% (tiga persen), untuk permohonan yang diajukan sejak 15 Oktober 2015 sampai dengan tanggal 31 Desember 2015;

2. 4\% (empat persen), untuk permohonan yang diajukan sejak 1 Januari 2016 sampai dengan tanggal 30 Juni 2016;

3. 6\% (enam persen), untuk permohonan yang diajukan sejak 1 Juli 2016 sampai dengan tanggal 31 Desember 2016.

Pemotongan tarif PPh Final tersebut hanya sampai 31 Desember 2016, dengan kata lain mulai 1 Januari 2017, tarif PPh Final atas revaluasi aktiva tetap kembali ke tarif semula, 10\%.

\section{TINJAUAN PUSTAKA}

\subsection{Pengertian Akuntansi}

Secara umum akuntansi adalah proses mengidentifikasi, mengukur, mengklasifikasi, dan mengikthisar sebuah transaksi ekonomi atau kejadian yang dapat menghasilkan data yang bersifat keuangan yang yang dapat digunakan dalam penPgambilan keputusan. Akuntansi adalah sebuah sistem informasi yang memberikan laporan kepada para pengguna informasi akuntansi atau kepada pihak-pihak yang memiliki kepentingan (stakeholders) terhadap hasil kinerja dan kondisi keuangan perusahaan (Hery 2015:6).

\subsection{Pengertian Pajak}

Berdasarkan Djoko Muljono (2010:5) pajak merupakan kontribusi kepada negara dan terutang oleh wajib pajak yang wajib dibayar, dipotong, atau dipungut berdasarkan undangundang dengan mendapat imbalan tidak secara langsung dan digunakan untuk kemakmuran rakyat.

\subsection{Pajak Penghasilan}

Pajak Penghasilan (PPh) diatur dalam Undang-undang No. 7 Tahun 1983 dan mulai berlaku pada 1 Januari 1984. Undang-undang Pajak Penghasilan mengatur pengenaan Pajak Penghasilan terhadap subjek pajak berkenan dengan penghasilan yang diperolehnya dalam tahun pajak. Subjek pajak dikenai pajak jika memperoleh penghasilan. Dalam undang-undang Pajak subjek pajak yang memperoleh penghasilan disebut sebagai Wajib Pajak.

\subsection{Pengertian Aset Tetap}

Pernyataan Standar Akuntansi Keuangan (2009:16) menyatakan bahwa aset tetap adalah aset yang berwujud yang diperoleh untuk difungsikan dalam suatu kegiatan produksi barang atau jasa, untuk direntalkan kepada pihak yang lain, atau untuk tujuan administrative dan dan penggunaannya diharapkan lebih dari satu periode. 
Tabel 2.1

Penggolongan Aset Tetap Menurut Ketentuan Perpajakan

\begin{tabular}{|c|c|c|c|}
\hline \multirow[b]{2}{*}{$\begin{array}{l}\text { Kelompok Harta } \\
\text { Berwujud }\end{array}$} & \multirow[b]{2}{*}{ Masa Manfaat } & \multicolumn{2}{|c|}{ Tarif Penyusutan } \\
\hline & & Garis Lurus & $\begin{array}{c}\text { Saldo } \\
\text { Menurun }\end{array}$ \\
\hline $\begin{array}{r}\text { I. Bukan Bangunan } \\
\text { Kelompok 1 } \\
\text { Kelompok 2 } \\
\text { Kelompok 3 } \\
\text { Kelompok 4 }\end{array}$ & $\begin{array}{l}4 \text { Tahun } \\
8 \text { Tahun } \\
16 \text { Tahun } \\
20 \text { Tahun }\end{array}$ & $\begin{array}{c}25 \% \\
12,5 \% \\
6,25 \% \\
5 \%\end{array}$ & $\begin{array}{c}50 \% \\
25 \% \\
12,5 \% \\
10 \%\end{array}$ \\
\hline $\begin{array}{ll}\text { II. } & \text { Bangunan } \\
\text { Permanen } \\
\text { Tidak Permanen }\end{array}$ & $\begin{array}{l}20 \text { Tahun } \\
10 \text { Tahun }\end{array}$ & $\begin{array}{l}5 \% \\
10 \%\end{array}$ & \\
\hline
\end{tabular}

\subsection{Revaluasi}

(Sumber: UU Pajak Penghasilan No. 36 Tahun 2008)

Revaluasi aset tetap adalah penilaian kembali aset tetap pada perusahaan, yang terjadi oleh karena timbulnya kenaikan harga atau nilai dari suatu aset tetap tersebut di pasaran pada saat melakukan revaluasi atau karena rendahnya pencatatan nilai aset tetap dalam laporan keuangan suatu perusahaan yang disebabkan terjadinya devaluasi atau sebab lain, sehingga nilai aset tetap yang tercatat dalam laporan keuangan suatu perusahaan tidak lagi mencerminkan nilai yang wajar.

\subsection{Revaluasi (Penilaian Kembali) Aset Tetap Menurut Peraturan Dalam Perpajakan}

Beberapa ketentuan umum revaluasi menurut aturan perpajakan dapat diringkas sebagai berikut ini:

1. Kegiatan revaluasi dapat dilakukan atas seluruh aset tetap termasuk tanah dengan status adalah hak milik atau hak guna bangunan.

2. Revaluasi dilakukan berdasarkan nilai pasar wajar aset tetap yang ditetapkan oleh ahli penilai atau perusahaan jasa penilai yang diberi izin oleh pemerintah.

3. Selisih revaluasi dikenakan pajak final sebesar $10 \%$.

4. Kegiatan Penilaian kembali atau revaluasi aset tetap tidak dapat dilakukan sebelum lewat jangka waktu lima tahun terhitung dari tanggal revaluasi terakhir.

5. Hasil revaluasi akan mempengaruhi nilai tercatat aset dan menjadi dasar penyusutan fiskal.

6. Revaluasi yang tidak memperoleh persetujuan Direktur Jenderal Pajak untuk penilaian kembali aset tetap, maka nilai revaluasi yang ditetapkan tidak dapat digunakan sebagai dasar melakukan penyusutan fiskal.

7. Perusahaan yang menjual aset yang telah direvaluasi sebelum masa penyusutan berakhir atau sebelum 10 tahun dari tanggal revaluasi, maka akan dikenakan tambahan pajak final sebesar selisih tarif terakhir dikurangi $10 \%(25 \%-10 \%=15 \%)$ dikali dengan keuntungan revaluasi aset.

\subsection{Pelaksanaan Penilaian Kembali (Revaluasi) Aset Tetap}

Penilaian kembali aset tetap merupakan salah satu bentuk kebijakan akuntansi terhadap seluruh aset tetap yang dimiliki perusahaan. Hal ini sesuai dengan Pernyataan Standar Akuntansi Keuangan No. 16 (Edisi Revisi 2012) "suatu entitas memilih model biaya atau model revaluasi sebagai kebijakan akuntansinya dan menerapkan kebijakan tersebut terhadap seluruh aset tetap dalam kelompok yang sama."

Untuk tujuan perpajakan, penilaian kembali (revaluasi) aset tetap dilaksanakan oleh perusahaan dengan berdasarkan pada peraturan yang telah ditetapkan pada pemerintah dalam 
hal ini melalui Keputusan Menteri Keuangan Republik Indonesia dan Surat Edaran dari Direktur Jenderal Pajak.

\section{METODE PENELITIAN}

\subsection{Jenis Penelitian}

Jenis penelitian yang digunakan dalam penelitian ini adalah kualitatif dengan perhitungan kuantitatif. Jenis data kualitatif dalam penenilitian ini adalah hasil observasi dengan pihak perusahaan yang merupakan objek penelitian sebagai data penunjang dalam penelitian ini.

\subsection{Jenis Data}

Jenis data dalam penelitian ini adalah:

1. Data Kuantitatif, merupakan data yang dapat diukur dalam satuan uang yaitu rupiah dan dinyatakan dalam rangka yang menunjukkan jumlah atau banyaknya sesuatu. Dalam penelitian ini, jenis data kuantitatif yang diperlukan berupa laporan keuangan, daftar revaluasi aset tetap perusahaan, daftar aset tetap dari perusahaan.

2. Data Kualitatif, yaitu data yang tidak dapat diukur dalam skala numerik. Dalam dalam penelitian ini, jenis data kualitatif yang diperlukan berupa penjelasan dari pihak perusahaan, sejarah dan struktur organisasi dalam perusahaan serta keterangan-keterangan tertulis dari pihak yang berwenang di perusahaan.

\subsection{Sumber Data}

Sumber data dalam penelitian ini yaitu:

1. Sumber-sumber internal yaitu, pihak yang berwenang dalam perusahaan tempat dimana peneliti melakukan penelitian ini.

2. Sumber data yang lain juga didapat dari study kepustakaan, melalui buku-buku refrensi yang berhubungan dengan judul penelitian ini yang memuat teori-teori yang dibutuhkan untuk mendukung penelitian ini, dan juga penelitian terdahulu mengenai judul peneliti saat ini.

\subsection{Metode Analisis Data}

Metode analisis data yang digunakan dalam penelitian ini adalah metode analisis deskriptif, yaitu metode pembahasan permasalahan yang sifatnya menggunakan, menggambarkan dan membandingkan suatu data atau keadaan dan menerangkan suatu keadaan sedemikian rupa sehingga dapat ditarik kesimpulan.

\section{HASIL ANALISIS DAN PEMBAHASAN}

\subsection{Hasil Penelitian}

Tabel 4.1

Aset Tetap Tanah Dan Bangunan PT. BANK SULUTGO Per 31 Desember 2016 Sebelum Revaluasi

(Dalam Rupiah)

\begin{tabular}{|l|r|r|r|}
\hline \multicolumn{1}{|c|}{ Aset Tetap } & Harga Perolehan & $\begin{array}{c}\text { Akumulasi } \\
\text { Penyusutan }\end{array}$ & \multicolumn{1}{c|}{ Nilai Buku } \\
\hline Tanah & 15.858 .862 .436 & & 15.858 .862 .436 \\
\hline Bangunan & 24.616 .386 .297 & 10.189 .351 .194 & 14.427 .035 .103 \\
\hline \multicolumn{1}{|c|}{ Jumlah } & $\mathbf{4 0 . 4 7 5 . 2 4 8 . 7 3 3}$ & $\mathbf{1 0 . 1 8 9 . 3 5 1 . 1 9 4}$ & $\mathbf{3 0 . 2 8 5 . 8 9 7 . 5 3 9}$ \\
\hline
\end{tabular}

(Sumber: PT. BANK SULUTGO) 


\section{Tabel 4.2}

Penilaian Aset Tetap Berdasarkan Nilai Pasar Wajar Berdasarkan Survei PT. BANK SULUTGO

(Dalam Rupiah)

\begin{tabular}{|c|c|}
\hline Aset Tetap & Nilai Pasar \\
\hline Tanah & 136.833 .140 .000 \\
\hline Bangunan & 52.548 .730 .000 \\
\hline Jumlah & 189.381.870.000 \\
\hline
\end{tabular}

\subsection{Pembahasan}

(Sumber: PT. BANK SULUTGO)

Dari hasil penelitian di atas terhadap daftar aset tetap dengan harga perolehan dan nilai penyusutan serta nilai pasar wajar sebagai acuan untuk melakukan revaluasi aset tetap pada PT. BANK SULUTGO, telah didapati hasil dari penelitian tersebut untuk menentukan $\mathrm{PPh}$ final $(6 \%)$ dari nilai selisih lebih yang disebabkan oleh revaluasi aset tetap sesuai dengan PMK-191 Tahun 2015 yang berlaku. Untuk lebih jelasnya akan dibahas dalam pembahasan di bawah ini.

Tabel 4.3

Selisih Revaluasi Aset Tetap PT. BANK SULUTGO

(Dalam Rupiah)

\begin{tabular}{|l|r|r|r|}
\hline \multicolumn{1}{|c|}{ Aset Tetap } & \multicolumn{1}{|c|}{ Nilai Pasar } & \multicolumn{1}{c|}{ Nilai Buku } & \multicolumn{1}{c|}{ Selisih Revaluasi } \\
\hline Tanah & 136.833 .140 .000 & 15.858 .862 .436 & 120.974 .277 .564 \\
\hline Bangunan & 52.548 .730 .000 & 14.427 .035 .103 & 38.121 .694 .897 \\
\hline Jumlah & $\mathbf{1 8 9 . 3 8 1 . 8 7 0 . 0 0 0}$ & $\mathbf{3 0 . 2 8 5 . 8 9 7 . 5 3 9}$ & $\mathbf{1 5 9 . 0 9 5 . 9 7 2 . 4 6 1}$ \\
\hline
\end{tabular}

(Sumber: PT. BANK SULUTGO dan Data Diolah)

Berdasarkan tabel 4.3, selisih revaluasi pada aset tetap berupa tanah adalah Rp.120.974.277.564.00 yang merupakan hasil pengurangan dari nilai pasar atas nilai buku aset tetap berupa tanah sebelum melakukan revaluasi yaitu Rp.136.833.140.000.00 dikurangi Rp.15.858.862.436.00, sedangkan selisih revaluasi aset tetap berupa bangunan adalah Rp.38.121.694.897.00 yang juga merupakan hasil pengurangan dari nilai pasar atas nilai buku aset tetap berupa bangunan sebelum revaluasi yaitu Rp.52.548.730.000.00 dikurangi Rp.14.427.035.103.00 sehinggah total selisih revaluasi menjadi Rp.159.095.972.461.00. Dari hasil selisih revaluasi tersebut nantinya akan dikenakan PPh final (6\%).

Tabel 4.4

Aset Tetap Tanah Dan Bangunan PT. BANK SULUTGO Melakukan Revaluasi (Dalam Rupiah)

\begin{tabular}{|l|r|r|r|}
\hline \multicolumn{1}{|c|}{ Aset Tetap } & \multicolumn{1}{c|}{ Nilai Pasar } & \multicolumn{1}{c|}{$\begin{array}{c}\text { Akumulasi } \\
\text { Penyusutan }\end{array}$} & \multicolumn{1}{c|}{ Nilai Buku } \\
\hline Tanah & 136.833 .140 .000 & & 136.833 .140 .000 \\
\hline Bangunan & 52.548 .730 .000 & 2.627 .436 .500 & 49.921 .293 .500 \\
\hline Jumlah & $\mathbf{1 8 9 . 3 8 1 . 8 7 0 . 0 0 0}$ & $\mathbf{2 . 6 2 7 . 4 3 6 . 5 0 0}$ & $\mathbf{1 8 6 . 7 5 4 . 4 3 3 . 5 0 0}$ \\
\hline
\end{tabular}

(Sumber: PT. BANK SULUTGO dan Data Diolah)

Berdasarkan tabel 4.4 , nilai akumulasi penyusutan pada aset tetap bangunan berbeda dengan dengan nilai akumulasi penyusutan sebelum melakukan revaluasi. Nilai tersebut terjadi dikarenakan nilai akumulasi penyusutan aset tetap bangunan yang tercatat dalam tabel 4.4 adalah nilai akumulasi penyusutan aset tetap bangunan dengan berdasarkan nilai pasar wajar, dan disusutkan untuk tahun pertama (tahun 2017) setelah melakukan revaluasi 
(Rp.52.548.730.000.00 x 5\%) sehingga nilai akumulasi penyusutan aset tetap bangunan menjadi Rp.2.627.436.500.00

Nilai buku aset tetap tanah dan bangunan pada PT. BANK SULUTGO mengalami perubahan di tahun selanjutnya, yaitu tahun 2017, setelah melakukan revaluasi. Nilai buku aset tetap tanah menjadi Rp.136.833.140.000.00 setelah melakukan revaluasi, sedangkan nilai buku aset tetap tanah sebelum melakukan revaluasi adalah Rp.15.858.862.436.00. Dalam hal ini didapati selisih Rp.120.974.277.564.00 setetlah melakukan revaluasi. Pada aset tetap bangunan nilai buku setelah melakukan revaluasi adalah Rp.49.921.293.500.00 sudah dikurangi dengan akumulasi penyusutan tahun pertama setelah melakukan revaluasi yaitu sebesar Rp.2.627.436.500.00 sedangkan nilai buku aset tetap bangunan sebelum melakukan revaluasi adalah Rp.14.427.035.103.00 sudah dikurangi dengan akumulasi penyusutan sebesar Rp.10.189.351.194.00 sehingga terjadi selisih nilai buku sebesar Rp.35.494.258.397.00.

Setelah melakukan revaluasi nilai buku aset tetap tanah dan bangunan PT. BANK SULUTGO meningkat menjadi Rp.186.754.433.500.00 di bandingkan dengan nilai buku aset tetap tanah dan bangunan sebelum melakukan revaluasi, yaitu sebesar Rp.30.285.897.539.00.

Tabel 4.5

Perhitungan PPh Final (6\%) Atas Selisih Revaluasi PT. BANK SULUTGO

(Dalam Rupiah)

\begin{tabular}{|c|c|c|}
\hline Aset Tetap & Selisih Revaluasi & PPh Final (6\%) \\
\hline Tanah & 120.974 .277 .564 & 7.258 .456 .654 \\
\hline Bangunan & 38.121 .694 .897 & 2.287 .301 .694 \\
\hline Jumlah & 159.095.972.461 & 9.545.758.348 \\
\hline
\end{tabular}

(Sumber: PT. BANK SULUTGO dan Data Diolah)

Tabel 4.5 menjelaskan tentang PPh final 6\% dari selisih atas revaluasi yang dilakukan oleh PT. BANK SULUTGO. Pada aset tetap tanah terdapat selisih revaluasi sebesar Rp.120.974.277.564.00 sehingga PPh final yang dikenakan sebesar Rp.7.258.456.654.00, sedangkan pada aset tetap bangunan terdapat selisih revaluasi sebesar Rp.38.121.694.897.00 sehingga PPh final yang dikenakan sebesar Rp.2.287.301.694.00. Dari selisih revaluasi kedua jenis aset tetap PT. BANK SULUTGO, yaitu tanah dan bangunan, total seluruh PPh final atas dilakukannya revaluasi pada PT. BANK SULUTGO adalah sebesar Rp.9.545.758.348.00.

\subsubsection{Peran Revaluasi Aset Tetap Terhadap Penghasilan Kena Pajak}

Pada umumnya, perusahaan selalu berusaha untuk meminimalkan besarnya jumlah laba yang tersaji pada laporan laba rugi komprehensif sesuai dengan peraturan yang berlaku tanpa melakukan kegiatan yang melanggar hukum. Hal ini dapat ditempuh perusahaan dengan menggunakan metode akuntansi yang diperbolehkan oleh peraturan yang berlaku. Salah satu hal yang paling tepat adalah dengan melakukan revaluasi aset tetap yang dimiliki perusahaan. Sehubungan dengan tujuan perpajakan, setiap perusahaan berupaya untuk menyajikan laporan laba rugi yang bernilai kecil agar beban pajak yang dibayarkan juga akan menjadi lebih kecil. 


\section{Tabel 4.6}

Perbandingan Laba Rugi Tahunan PT. BANK SULUTGO - Melakukan Revaluasi dan Sebelum Melakukan Revaluasi Per 31 Desember 2016

(Dalam Rupiah)

\begin{tabular}{|l|r|r|}
\hline \multicolumn{1}{|c|}{ Nama Akun } & $\begin{array}{r}\text { Tahun 2016 / 31 Des } \\
\text { Sebelum Revaluasi }\end{array}$ & $\begin{array}{r}\text { Tahun 2016 / 31 Des } \\
\text { Sebelum Revaluasi }\end{array}$ \\
\hline PENDAPATAN DAN BEBAN OPERASIONAL & & \\
Pendapatan Bunga & 2.895 .586 .126 .438 & 2.895 .586 .126 .438 \\
Beban Bunga & $(1.888 .686 .428 .809)$ & $(1.888 .686 .428 .809)$ \\
Jumlah Pendapatan Bunga -Bersih & $\mathbf{1 . 0 0 5 . 8 9 9 . 6 9 7 . 6 2 9}$ & $\mathbf{1 . 0 0 5 . 8 9 9 . 6 9 7 . 6 2 9}$ \\
PENDAPATAN OPERASI LAINNYA & & \\
Provisi Dan Komisi Lainnya & 21.156 .539 .670 & 21.156 .539 .670 \\
Pendapatan Administrasi & 39.747 .985 .266 & 39.747 .985 .266 \\
Pendapatan Denda & 13.077 .694 .992 & 13.077 .694 .992 \\
Keuntungan Dari Perubahan Nilai Wajar & & \\
Aset Keuangan & 220.536 .779 .920 & 220.536 .779 .920 \\
Pendapatan Lainnya & 267.758 .456 & 267.758 .456 \\
Jumlah Pendapatan Operasi Lainnya & $\mathbf{2 9 4 . 7 8 6 . 7 5 8 . 3 0 4}$ & $\mathbf{2 9 4 . 7 8 6 . 7 5 8 . 3 0 4}$ \\
BEBAN PENYISIHAN KERUGIAN ASET & & \\
PRODUKTIF DAN ASET NON PRODUKTIF & $\mathbf{( 8 . 4 5 4 . 2 3 7 . 0 0 6 )}$ & $\mathbf{( 8 . 4 5 4 . 2 3 7 . 0 0 6 )}$ \\
BEBAN OPERASIONAL LAINNYA & & \\
Beban Personalia & $(515.594 .666 .107)$ & $(515.594 .666 .107)$ \\
Beban Umum Dan Administrasi & $(251.811 .597 .441)$ & $(249.905 .512 .696)$ \\
Beban Promosi & $(26.083 .950 .995)$ & $(26.083 .950 .995)$ \\
Beban Premi Program Penjaminan Pemerintah & $(21.979 .477 .021)$ & $(21.979 .477 .021)$ \\
Kerugian Dari Perubahan Nilai Wajar Aset Keuangan & $(200.311 .769 .470)$ & $(200.311 .769 .470)$ \\
Jumlah Beban Operasi Lainnya & $\mathbf{( 1 . 0 1 5 . 7 8 1 . 4 6 1 . 0 3 4 )}$ & $\mathbf{( 1 . 0 1 3 . 8 7 5 . 3 7 6 . 2 8 9 )}$ \\
LABA OPERASIONAL & $\mathbf{2 7 6 . 4 5 0 . 7 5 7 . 8 9 3}$ & $\mathbf{2 7 8 . 3 5 6 . 8 4 2 . 6 3 8}$ \\
PENDAPATAN (BEBAN) NON OPERASIONAL & & \\
Pendapatan Non Operasional & 10.275 .776 .844 & 10.275 .776 .844 \\
Beban Non Operasional & $(29.107 .970 .705)$ & $(29.107 .970 .705)$ \\
Jumlah Beban Non Operasional - Bersih & $\mathbf{( 1 8 . 8 3 2 . 1 9 3 . 8 6 1 )}$ & $\mathbf{( 1 8 . 8 3 2 . 1 9 3 . 8 6 1 )}$ \\
LABA SEBELUM PAJAK PENGHASILAN & $\mathbf{2 5 7 . 6 1 8 . 5 6 4 . 0 3 2}$ & $\mathbf{2 5 9 . 5 2 4 . 6 4 8 . 7 7 7}$ \\
BEBAN PAJAK PENGHASILAN & & \\
Beban Pajak Kini & & \\
Manfaat Beban Pajak Tangguhan & $(88.825 .802 .000)$ & $(89.302 .323 .250)$ \\
Jumlah Beban Pajak Penghasilan - Bersih & 4.625 .317 .329 & 4.625 .317 .329 \\
LABA BERSIH TAHUN BERJALAN & $\mathbf{1 7 3 . 2 0 0 . 4 8 4 . 6 7 1 )}$ & $\mathbf{( 8 4 . 6 7 7 . 0 0 5 . 9 2 1 )}$ \\
& & $\mathbf{1 7 4 . 8 4 7 . 6 4 2 . 8 5 6}$ \\
\hline
\end{tabular}

(Sumber: PT. BANK SULUTGO dan Data Diolah)

Berdasarkan tabel 4.6 maka dapat diketahui bahwa laba sebelum Pajak Penghasilan pada saat melakukan revaluasi berjumlah Rp.257.618.564.031.00 sedangkan sebelum melakukan revaluasi berjumlah Rp.259.524.648.777.00. Laba tersebut menunjukan posisi laba sebelum koreksi fiskal. Untuk memperoleh laba fiskal perusahaan maka jumlah laba sebelum Pajak Penghasilan ditambah dengan jumlah koreksi fiskal sebesar Rp.97.684.644.258.00 sehingga laba fiskal perusahaan atau Penghasilan Kena Pajak pada 
saat melakukan revaluasi berjumlah Rp.355.303.208.000.00, sedangkan jika tidak melakukan revaluasi berjumlah Rp.357.209.293.035.00.

\subsubsection{Penetapan Pajak Penghasilan PT. BANK SULUTGO}

Penghasilan Kena Pajak yang dikenai pada PT. BANK SULUTGO sesuai dengan UU Pajak Penghasilan Pasal 31 huruf e. Dimana tarif pajak yang dikenai adalah 25\% untuk tahun buku 2010 dan selanjutnya, sedangkan 28\% untuk tahun buku 2009 dan sebelumnya.

Untuk memperoleh Beban Pajak Penghasilan diambil dari Penghasilan Kena Pajak perusahaan yang merupakan laba fiskal kemudian dikali dengan 25\% sehingga Beban Pajak Penghasilan yang diperoleh pada saat melakukan revaluasi menjadi Rp.88.825.802.000.00 (Rp.355.303.208.000.00 x 25\%), sedangkan jika tidak melakukan revaluasi maka Beban Pajak Penghasilan pada PT. BANK SULUTGO menjadi Rp.89.302.323.250.00 (Rp.357.209.293.035.00 x 25\%). Dalam hal revaluasi terjadi penurunan Beban Pajak Penghasilan pada PT. BANK SULUTGO.

Di tahun buku 2016 PT. BANK SULUTGO terdapat Pajak Dibayar Dimuka atau PPh Pasal 25 pada perusahaan. Untuk menentukan jumlah Taksiran Pajak Penghasilan Badan kurang bayar yaitu dari Beban Pajak Penghasilan dikurangi dengan Pajak Dibayar Dimuka atau PPh Pasal 25 dari perusahaan. Dalam tahun buku 2016 PT. BANK SULUTGO, jumlah Pajak Dibayar Dimuka perusahaan berjumlah Rp.82.263.436.493.00

Berdasarkan penjelasan diatas maka Beban Pajak Penghasilan Badan pada saat melakukan revaluasi yang berjumlah Rp.88.825.802.000.00 dikurangi dengan Jumlah Pajak Dibayar Dimuka perusahaan yang berjumlah Rp.82.263.436.493.00 sehingga Pajak Kurang Bayar dari perusahaan berjumlah Rp.6.562.365.507.00 Akan tetapi jika tidak melakukan revaluasi maka Pajak kurang bayar dari perusahaan akan berbeda, karena lebih tingginya Beban Pajak Penghasilan Badan pada saat tidak melakukan revaluasi yang berjumlah Rp.89.302.323.250.00 dikurangi dengan Pajak Dibayar Dimuka dari perusahaan berjumlah Rp.82.263.436.493.00 sehingga Pajak Kurang Bayar dari perusahaan adalah sebesar Rp.7.038.795.757.00.

Tabel 4.7

Selisih Revaluasi dan Perbandingan Beban Pajak Penghasilan Pada Saat Melakukan Revaluasi dan Tidak Melakukan Revaluasi Pada PT. BANK SULUTGO Per 31 Desember 2016

(Dalam Rupiah)

\begin{tabular}{|l|r|r|}
\hline & Sesudah Revaluasi & \multicolumn{1}{|c|}{ Sebelum Revaluasi } \\
\hline PPh Final Revaluasi 6\% & 9.545 .758 .348 & - \\
\hline Penghasilan Kena Pajak & 355.303 .208 .000 & 357.209 .293 .035 \\
\hline Beban Pajak Penghasilan & 88.825 .802 .000 & 89.302 .323 .250 \\
\hline Pajak Dibayar Dimuka & 82.263 .436 .493 & 82.263 .436 .493 \\
\hline $\begin{array}{l}\text { Beban Pajak Penghasilan - Setelah } \\
\text { Dikurangi Pajak Dibayar Dimuka }\end{array}$ & 6.562 .356 .507 & 7.038 .795 .757 \\
\hline
\end{tabular}

(Sumber: Data Diolah)

\section{KESIMPULAN DAN SARAN}

\subsection{Kesimpulan}

Peran revaluasi aset tetap dalam penetapan pajak penghasilan pada PT. BANK SULUTGO adalah menjadi naiknya beban penyusutan pertahunnya dengan dasar perhitungan pada nilai buku sesudah melakukan revaluasi, sehingga berdampak pada laba fiskal perusahaan yang menjadi dasar pengenaan Penghasilan Kena Pajak. Jika laba fiskal perusahaan menurun oleh sebab bertambahnya beban penyusutan maka Penghasilan Kena Pajak juga akan menurun. 
Penetapan PPh final atas selisih revaluasi aset tetap yang dilakukan oleh PT. BANK SULUTGO sudah sesuai dengan PMK-191 Tahun 2015 atas tahun buku desember 2016, dan perhitungan Penghasilan Kena Pajak perusahaan sudah sesuai dengan UU PPh Pasal 31 huruf e untuk tahun buku 2010 dan selanjutnya

\subsection{Saran}

Karena penilaian kembali aset tetap bersifat pilihan bukan suatu keharusan, maka PT. BANK SULUTGO perlu mempertimbangkan dengan matang mengenai keuntungan maupun kerugian dalam melakukan penilaian kembali aset tetap sebelum memutuskan untuk menilai kembali aktiva tetapnya. Salah satu pertimbangan yang harus diutamakan adalah bahwa revaluasi aset tetap jangan sampai merusak profitabilitas perusahaan, karena merupakan tujuan perusahaan untuk menjaga profitabilitas perusahaan.

\section{DAFTAR PUSTAKA}

. 2000. Peraturan Pemerintah Nomor 138 Tahun 2000 Tentang Perhitungan Penghasilan Penghasilan Kena Pajak dan Pelunasan Pajak Penghasilan dalam Tahun Berjalan. Jakarta

. 2008. Undang-undang Nomor 36 Tahun 2008 Tentang Perubahan Keempat Atas Undang-undang Nomor 7 Tahun 1983 Tentang Pajak Penghasilan mulai berlaku pada tanggal 1 Januari 2009. Jakarta

. 2015. Peraturan Menteri Keuangan Nomor 191 Tahun 2015 Tentang Penilaian Kembali Aktiva Tetap Untuk Tujuan Perpajakan Bagi Permohonan Yang Diajukan Pada Tahun 2015 Dan Tahun 2016 mulai berlaku pada tanggal 20 Oktober 2015. Jakarta

2015. Surat Edaran Direktur Jenderal Pajak Nomor 02/PJ/2015 Tentang Penegasan Atas Pelaksanaan Pasal 31 e mulai berlaku pada tanggal 9 Januari 2015. Jakarta

Hery. 2015. Pengantar Akuntansi, Comprehensive Edition. Grasindo, Jakarta.

Ikatan Akuntansi Indonesia. 2009. Standar Akuntansi Keuangan. Penerbit Salemba Empat. Jakarta.

Ikatan Akuntansi Indonesia. 2012. Standar Akuntansi Keuangan. Salemba Empat, Jakarta.

Katuuk., Yolanda., C. 2013. Analisis Perencanaan Pajak Melalui Revaluasi Aset Tetap Pada PT. ANGKASA PURA I (Persero) Bandara Sam Ratulangi. Jurnal EMBA, Unsrat. Manado

Lubis, Irsan. 2015. Mahir Akuntansi Pajak Terapan. Penerbit Andi, Yogyakarta.

Mardiasmo. 2018. Perpajakan, Edisi Terbaru. Penerbit Andi. Yogyakarta.

Muljono, Djoko. 2010. Hukum Pajak. Konsep, Aplikasi Dan Penuntun Praktis. Penerbit Andi. Yogyakarta.

Republik Indonesia. 2002. Keputusan Menteri Keuangan No.486/KMK.03/2002 Tentang Penilaian Kembali Aktiva Tetap Perusahaan Untuk Tujuan Perpajakan. Jakarta. 